\title{
Biocontrol of Fusarium wilt of banana: Key influence factors and strategies
}

\author{
Guo Gang ${ }^{1,2,3 \#}$, Wang Bizun ${ }^{1,2 \#}$, Ma Weihong ${ }^{1,2}$, Li Xiaofen ${ }^{1,2}$, Yang Xiaolin ${ }^{1,4}$, Zhu Chaohua ${ }^{4}$, \\ Ming Jianhong ${ }^{1,2 \star}$ and Zeng Huicai ${ }^{1,2,3^{*}}$ \\ ${ }^{1}$ Haikou Experimental Station/Hainan Key Laboratory of Banana Genetic Improvement, Chinese Academy of Tropical \\ Agricultural Science (CATAS), Haikou 570102, Hainan, China. \\ ${ }^{2}$ Banana Research and Development Department, National Center of Important Tropical Crops Engineering and \\ Technology Research, Haikou 570102, Hainan, China. \\ ${ }^{3}$ Institute of Tropical Bioscience and Biotechnology, CATAS, Haikou 571101, Hainan, China. \\ ${ }^{4}$ College of Environment and Plant Protection, Hainan University, Haikou 570228, Hainan, China.
}

Accepted 8 September, 2013

\begin{abstract}
Fusarium wilt of banana, caused by Fusarium oxyspoum f. sp. cubense (Foc), is one of the most important and destructive diseases of banana, and is known to be a major biotic limiting factor for the development of the present banana industry. Biocontrol on the destructive disease, the use of antagonist as biocontrol agents (BCAs) against Foc, constitutes an effective option for the management of the disease. The effectiveness of biocontrol agents depends on a range of biological and physico-chemical factors, including the type and properties of the biocontrol agents, the obstacles to the initial colonization of antagonists, as well as the variation factors after initial colonization. Various strategies can be implemented to optimize the biocontrol efficacy, such as the use of endophytes from banana plants as BCAs (favorably Bacillus spp.), the development of water and nutrition retaining agent, the application of proper carrier for BCAs, the restoration of soil biodiversity, and combined management of nematodes disease and Fusarium wilt. In this review, elements affecting the biocontrol efficacy of Fusarium wilt are analyzed in detail, and strategies to promote the biocontrol effects are proposed. Besides, the concept of "post-indigenousness" and "post-indigenous microbes" were firstly suggested.
\end{abstract}

Key words: Fusarium wilt of banana, biocontrol, Fusarium oxysporum f. sp. cubense (E.F. Smith) Snyder \& Hansen, Bacillus sp., endophtic bacteria.

\section{INTRODUCTION}

Fusarium wilt of banana, also called Panama disease, is caused by Fusarium oxysporum f. sp. cubense (E.F. Smith) Snyder \& Hansen, shortly as Foc (Stover, 1962). Fusarium wilt is known to be one of the most important and destructive diseases of banana, which is especially serious in the Central and South Americas, parts of Africa
(Viljoen, 2002), Sri Lanka, Burma, Thailand, Indonesia and the Philippines, resulting in heavy enormous economic losses each year (Ploetz, 1994; Stover et al., 1987). In the recent ten years, banana plantation areas in China, influenced by Fusarium wilt, have decreased dramatically, especially in Guandong, Hainan, Fujian provinces. 
The fungus infects banana plants through the roots and invades the vascular tissue (xylem), causing external symptoms like gradual wilting, progressive yellowing of banana leaves (spreads from leaf margins, and from older leaves to younger leaves), eventual collapse at the petiole, and longitudinal splitting of the outer leaf sheaths in the pseudostem (Yin et al., 2011). The distinguishing internal symptoms of the disease is the typical discoloration of vascular tissues (in roots, corm, pseudostem, fruit stalk) varying from light yellow to dark brown, which appears first in the outer or oldest leaf sheath, then extends up to the pseudostem (Ploetz, 2006). Eventually, the disease leads to the death of banana plants.

The pathogenic isolates of Foc have been traditionally grouped into four physiological races based on pathogenicity to host cultivars under field condition (Fourie et al., 2009). F. oxysporum f. sp. cubense race 1 (Foc R1) attacks 'Gros Michel', 'Lady Finger' (AAB) and 'Silk' (AAB) varieties. Foc R2 infects cultivar 'Bluggoe' (ABB), while Foc R3 infects Heliconia spp. (a close relative of banana). And Foc R4 is able to attack cultivar Cavendish and all cultivars that are susceptible to Foc1 and Foc2 (Persley, 1987; Ploetz, 1990).

Banana production was once severely threatened by Fusarium wilt caused by Foc R1. The disease almost devastated the 'Gros Michel'-based banana industry in the Central American and Caribbean during the mid1900s (Ploetz, 1994). This adversity persisted until the introduction of Cavendish cultivars, which are unsusceptible to Foc R1 and Foc R2 in tropical banana-growing regions (Fernández-Falcón et al., 2003). However, the prosperity did not last long. The Cavendish cultivars had then been found highly susceptible to a new race of Foc, Foc R4 (Ploetz and Pegg, 2000). Economic losses worldwide are enormous. It brings to the spiteful reality that the banana industry is once again threatened by Fusarium wilt.

Fusarium wilt is destructive because it seriously hampers banana production and is difficult to manage. $F$. oxysporum are able to infect more than 100 plants, and are divided into more than 120 host-specific forms, known as formae speciales (Minerdi et al., 2008). Foc, generally considered to be one of the most destructive formae speciales of $F$. oxysporum (Ploetz, 1990), is soil-borne and has strong saprophytic ability. The pathogen can survive in the soil for several decades by producing spores (specifically, chlamydospores), which will re-infect the susceptible banana plants (Stover, 1962). This adds to the difficulty of disease management.

Till date, results from disease management studies have been disappointing. No effective and efficient control strategies available can satisfy the needs for the management of disease worldwide. Although, Huang et al. (2012) reported that Chinese leek-banana rotation is an efficient way for controlling banana Fusarium wilt, the method is not economical because Chinese leek is in low need in the market. Beside, crop rotation tends to have limited effec- tiveness once a disease outbreak occurs because of its soil-born nature and strong vitality (Fravel et al., 2003). Soil disinfection using chemicals or pesticides are not recommended due to environmental and human health concerns. And fumigated soils with methyl bromide can be re-infected in two or three years in fields with susceptible cultivars (Stover, 1958). Developing resistant banana cultivars may solve this problem but such efforts are progressing slowly (Stover and Buddenhagen, 1986; Hwang and Ko, 2004). Considering the urgency of the disease, a complementary approachformanaging Fusarium wilt involves the biological control (or biocontrol), an important component of integrated disease management programs, specifically, in this case, is to use naturally occurring antagonists and active substances (viruses, bacteria, fungi, active substances of natural origin) as biocontrol agents (BCAs) for disease management.

When compared with other approaches, the use of BCAs is proved to be an ecologically safe strategy for disease management. However, the technology is still in its infancy. Enormous efforts should be still contributed to the development of effective and safe BCAs for comer-cial application. This review would focus on the elements affecting the biocontrol efficacy of Fusarium wilt, the points needed to be considered in the development of $\mathrm{BCAs}$, and the corresponding strategies to improve the biocontrol efficacy, aiming to provide guidance for the biocontrol of Fusarium wilt and point the way forward for enhanced utilization of BCAs.

\section{ELEMENTS AFFECTING THE BIOCONTROL OF FUSARIUM WILT AND CORRESPONDING STRATEGIES TO IMPROVE THE BIOCONTROL EFFICACY}

It is a systematic work to use biological agents to control banana Fusarium wilt. In order to achieve ideal results, we should at least take into account the following elements: the type and properties of the biocontrol agents, the obstacles to the initial colonization of antagonists, as well as the variation factors after initial colonization.

\section{The type and properties of the biocontrol agents}

The first step to achieve effective biocontrol is to find the suitable potential biocontrol agents (BCAs). A primary consideration in the selection of antagonists as BCAs for field application is their type and properties, which directly or indirectly affect the biocontrol efficacy, the production process, the post-processing, as well as the storage and transportation. Production methods for biocontrol agents must be at low cost and yield viable, highly effective propagules of high concentrations. Also, these propagules, such as spores, must be amenable to long-term storage as dry preparations (Jackson, 1997).

Previous studies and experiences implied that Bacillus 
species serves as ideal candidates for viable BCAs (Yilmaz et al., 2005; Bertagnolli et al., 1996; Szczech and Shoda, 2004; Farhana et al., 2011; Govindasamy et al., 2011; Tan et al., 2013). Bacillus spp. strains are advantageous as BCAs because they are tolerant to adverse environmental stresses by producing endospores, such as heat and desiccation (Schallmey et al., 2004). At present, a variety of strains of Bacillus spp. have been extensively applied as BCAs against soil-borne plant diseases (Gurr et al., 2005), including Rhizoctonia (Yu et al., 2002) and Fusarium (Schisler er al., 2002; Sun et al., 2011), which have been proven to bring about high biocontrol efficacy. In addition, using Bacillus spp. strains as BCAs, the post-processing costs are easy to control, and the storage and transportation conditions needed could be easily fulfilled (Schallmey et al., 2004). On the other hand, the application of other microorganisms as BCAs, such as nonpathogenic F. oxysporum ( $\mathrm{Nel}$ and Steinberg, 2006), Trichoderma spp. (Thangavelu et al., 2004), has been demonstrated to result in high cost of production, storage and transportation.

\section{Obstacles to the initial colonization of antagonists}

The second key point needed to be considered is the colonization of antagonistic microbes. The biocontrol efficacy of the BCAs largely depends on the ability of the antagonistic microbes to colonize the plant root and the rhizosphere, and to produce substances which inhibit pathogens. The colonization of antagonistic microbes is hampered by several natural barriers. Obstacles to the initial colonization refers to the first set of natural barriers encountered by the antagonistic microbes after the application of BCAs, including the predation and phagocytosis from soil protozoa (Ekelund et al., 2001; Ronn et al., 2002), inhibition from the exudates of indigenous microbes (Bolwerk et al., 2003) or plant roots (Chao et al., 1986), the competition with indigenous microbes for ecological sites, nutrients and energy.

Normally, influenced by these barriers, the population of most antagonistic microbes reduced drastically in the first 2 to 3 days after the application of the BCAs (Christoffersen et al., 1995). However, BCAs usually must maintain a certain population of the antagonistic microbes to obtain acceptable levels of disease suppression (Wang et al., 2011). Thus, in order to achieve satisfactory biocontrol efficacy, appropriate measures should be taken to help the antagonistic microbes get through this hard time. One of the alternatives is to increase the original population of the antagonistic microbes in the BCAs, ensuring that a considerable part of the population survive this adverse phase under the regulation of environmental factors. Another recommendation is to apply BCAs repeatedly to maintain certain levels of the antagonistic microbes. Repeated applications of BCAs can be achieved by distributing the BCAs through the irrigation water.

\section{Predation and phagocytosis from soil protozoa}

Predatory protozoa in the soil to some extent act as the regulator of the population of soil bacteria and fungi (Bird et al., 2003; Ingham et al., 1985). They prey selectively on certain bacteria and fungi, thus exert an effect on the population and diversity of their prey (Burke et al., 2003). The antagonistic microbes in the BCAs, of course, are affected inevitably by this regulation. One proposed solution to counteract this regulation is to inoculate the BCAs directly into the leaves or stems of banana plant through drip injection, but not to apply them into the soil. Specifically, the approach means to inject the BCAs intermittently into the plant vessel from up to down under the law of gravity, and let them spread into the cell eventually. However, one leading problem of this method is the increased costs. Advanced techniques are needed to be developed in order to reduce the costs to an acceptable level for large-scale field applications.

Besides, studies have shown that the spatial heterogeneity of soil may have something to do with the stability of the predator-prey relationship, since certain soil structures are beneficial for the survival of bacteria, for example, in the case that the spaces in the soil are suitable for bacteria to live in but are inaccessible to protozoa (Wardle, 2006). Soil aggregates are clumps of soil particles that are held together by moist clay, organic matter (like roots and fibrous roots), gums (from bacteria and fungi) and by fungal hyphae. Study revealed that well-aggregated soil is thought to be a very desirable habitat for bacteria (Wardle, 2006). Bacteria tend to accumulate inside soil aggregates because this environment provides them with micro-ecological sites that are not accessible to certain protozoa, that is to say, bacteria in this environment are less likely to be eaten by soil animals like protozoa and mites. Such knowledge gives us some clues on the application of BCAs- to make the carrier of BCAs into the structure of soil aggregates. This approach can to some extent protect the antagonistic microbes from the prey of indigenous predatory protozoa, thus conserving a substantial number of the microbes as a result. One recommendation currently, is to apply resin-coated controlled-release materials as the carrier of BCAs (Ko et al., 1996; Lunt, 1968).

\section{Inhibition from the exudates of indigenous microbes or plant roots}

A substantial amount of studies have reported that certain exudates of indigenous microbes and plant roots exert an inhibitory effect on heterologous microorganisms (Quintana et al., 2009; Bais et al., 2006; Hirsch et al., 2003). In addition, plants tend to develop an induced systemic resistance to heterologous microorganisms (Pieterse et al., 1998). These effects exert strong negative influences on the colonization of the heterologous antagonistic microbes in banana plants. To overcome these difficulties, 
a proposal is to screen active antagonistic microbes from the endophytic strains of healthy banana plants (Lian et al., 2008). The use of endophytes as antagonist is of great interest because of their ability to colonize plant tissue and produce antibiotics in situ (Sessitsch et al., 2004).

Of course, the endophytes isolated from a certain plant tend to be plant tissue and variety specific. That is to say, the endophytes from one cultivar might not be endophytic to another cultivar due to genetic diversity, which may stand in the way of the colonization process. In fact, the variety of banana cultivars in China is relatively uniform geographically, mostly Brazil and Williams, both belonging to Musa AAA group. Normally, it would not be difficult for the endophytes to colonize the varieties from the same group. Our recent studies have preliminarily confirmed the feasibility of endophytes (Wang et al., 2011).

When the BCAs have to be applied into soil, to overcome the inhibition from indigenous microbes and plant roots, or the "induced systemic resistance" mentioned above, a recommended option is to introduce a cover for the antagonistic microbes, which shelters the microbes from antimicrobial agents and environmental stress by acting as a physical barrier. For example, to entrap the biocontrol agents in capsule-like materials (Candela and Fouet, 2006) or coated and controlled-release materials mentioned above. The advantages of entrapped BCAs include: a controlled release of agent (controlled by the environment and the properties of the entrapment materials); easy handing and prolonged shelf life; protection against extreme environmental conditions.

\section{The competition with indigenous microbes for ecological sites, nutrients and energy}

The colonization of the antagonists is also impacted tremendously by indigenous microbes through competition for ecological sites, nutrients and energy (Hyakumachi, 2000). The competition, creating a nutrient-limiting environment, determines how different microbial populations coexist in the same ecosystem. Competition for essential resources is a factor that determines the survival of all organisms (Hyakumachi, 2000). The biocontrol fails if the antagonistic organisms are out-competed by other indigenous microbes in the soil for a limited essential resource. Thus, the antagonists must have the ability to use energy substrates and nutrients at low concentrations. Studies revealed that strains of Pseudomonas fluorescens and Trichoderma harzianum showed antagnostic effect on Foc. (Rujappan et al., 2002; Saravanan et al., 2003).

\section{Obstacles to the long-term colonization of antagonists: The variation factors after initial colonization}

The variation factors after initial colonization means the factors that affect the long-term colonization of antagonists. Fusarium wilt is a typical soil-borne disease. To achieve ideal biocontrol efficacy, the antagonists must colonize the rhizosphere soil and sustainedly occupy favorable ecological sites in the environment. Previous studies have illustrated that the long-term colonization of antagonists is correlated to soil moisture (or the water content of soil), temperature, soil aeration, $\mathrm{pH}$, soil salinity, as well as the continuous supply of nutrients (Sessitsch et al., 2004; Bashan et al., 1991; Bevivino et al., 2005; Cavaglieri et al., 2005; de-Bashan and Bashan, 2008).

According to latest studies, rhizosphere bacteria exist not in the traditional recognized status (planktonic cells), but in biofilms (Webb et al., 2003). A biofilm is "a structured community of microorganisms encapsulated within a self-developed polymeric matrix and adherent to a living or inert surface" (http://en.wikipedia.org, 20090205), formed by an aggregate of microorganisms in which cells adhere to each other and/or to a surface. In nature, biofilms constitute a protected growth modality allowing bacteria to survive in hostile environments (Rinaudi and Giordano, 2010). In this case, we believe biofilm is the best mode for antagonists to occupy heterogeneous habitats, acting as a physical barrier sheltering the antagonists from antimicrobial agents and environmental stress. Thus, favorableconditionsshould be provided to facilitate the formation of biofilm in practice. As indicated by Chang and Halverson (2003), the formation of rhizosphere bacterial biofilm is mainly affected by water moisture, nutritional status and environmental parameters.

\section{Soil moisture}

One of the most significant requirements for biofilm forma tion is sufficient moisture. In banana plantations, soil moisture affects the structure of soil aggregates, and is significantly related to soil aeration, temperature, entropy and $\mathrm{pH}$. Banana plants need plenty of water and fertilizer to grow (Goenaga and Irizarry, 1998), due to their large stems and leaves, shallow roots, rapid growth and high yield. They do best in areas of high humidity (50\% or more) and require regular applications of fertilizer. The growing periods and yield of banana plants depend largely on the rational management of fertilizer and water. In China, areas under banana cultivation are mostly dry slopes, platforms, plateaus, or plains in short of water. Irrigation in these areas is normally not convenient (Xia, 2011). The large-scale banana plantations are mostly watered through well irrigation, ditches-guided irrigation, showering irrigation via perforated pipe, or microjet irrigation (Chen, 2001). These irrigation means, although solve the water shortage problem to some extent, are far from enough to satisfy the sustained demand of banana plants for continuous water supply, especially in the vegetative stage, flower bud differentiation stage, flowering and fruit ripening stages. Besides, the irrigation means mentioned above are all based on high costs, which tend to benefit the large-scale plantations owners more and are relatively uneconomical to the smallholders.

Banana plant is also vulnerable to water logging, and the 
soil aeration condition directly determines the growth status of its root system (Goenaga and Irizarry, 1998). Waterlogging reduces yield and plant size, restricts root growth, causes shallow root systems, and stops the active uptake of nutrients (Aguilar et al., 2008). In a nutshell, banana plant is vulnerable to both blood (waterlogging) and drought. In this dilemma, most plantations have difficulty in maintaining a balanced water supply throughout the whole growing season, which inevitably results in the intermittent shortage of water. This problem will, undoubtedly, lead to changes in soil microbial communities, mostly, dramatic decrease in the population of soil microbes (which are irreversible for at least one growing season). This is the fundamental reason why most BCAs do not have a sustained effect in practice, according to our continued investigation in the recent 4 years (Guo et al., unpublished data).

Sustained water supply in rhizosphere soil leads to favorable rhizosphere environments for the biofilms formation of antagonists. Through biofilms, the population of antagonists in the rhizosphere can maintain a balance for quite a long time, which in turn prolongs the persistence of the colonization of the of antagonists. In conclusion, from our point of view, the population of antagonists is mostly dependent on the stability of sustained water supply in soil. In standard large-scale plantations, this demand can be satisfied through microjet irrigation and drip irrigation facilities. However, in small plantations, where it is not profitable and feasible to set up these facilities, a recommended option is to apply water retaining agents in rhizosphere soil.

There are two types of water retaining agents nowadays, one is chemical and the other is bioactive. Poly-y-glutamic acid (Zeng et al., 2013), in short $\mathrm{y}$-PGA, act as a new kind of bioactive water retaining agent in agricultural and environmental applications. It is a biodegradable, water- soluble amino acid polymer with a molecular weight ranging from about 10,000 up to 2 millions, generated by the microbial fermentation in nature (Zeng et al., 2013). It is normally composed of about 5,000 glutamic acids molecules or mono units, with a free carboxyl group on the a-carbon atom of each repeating unit (Do et al., 2011).

Because of the repulsion of the negatively charged carboxyl, the chain space is extended to be particularly large. The interaction between molecules is strong even when $\mathrm{y}$-PGA is in low concentrations, which makes it an ideal material for super absorbent (Candela and Fouet, 2006). Studies have revealed that $Y$-PGA can effectively absorb soil water, and can reach a maximum water absorption coefficient of 1108.4 (Tsujimoto et al., 2010). Due to its nature of economical costs, biodegradability and water absorption, $y-P G A$, as a water retaining agent, can be used to change soil aggregates structure, maintain soil moisture, and conserve fertilizer in soil. In our study, we have found several $y$-PGA-producing strains that are antagonistic against Foc (Guo et al., unpublished data) under the application for a patent. Further studies are still under way to screen more efficient strains. Undoubtedly, the application of these bacteria as BCAs would bring more efficiency.

\section{Nutritional status and environmental parameters}

Nutritional status and several environmental parameters are also key factors that influence the formation of biofilm (Pan et al., 2010), which further affect the persistence of the colonization of the antagonists, including carbon source, amount of nitrate, phosphate, calcium and magnesium as well as the effects of osmolarity and $\mathrm{pH}$ (Rinaudi et al., 2006).

Availability of nutrition in the form of glucose results in increased biofilm formation of bacteria (Shera et al., 2006; Revdiwala et al., 2012). Increased levels of phosphate, $\mathrm{Ca}^{2+}, \mathrm{Mg}^{2+}$ enhance biofilm formation, whereas osmotic agents, such as $\mathrm{NaCl}$ and sorbitol negatively affect biofilm formation through an osmotic effect as their concentrations increase (Rinaudi et al., 2006). Besides, temperatures and $\mathrm{pH}$ are also factors that affect biofilm formation (Pettit et al., 2010), and the effects differ from one bacterial species to another. Taken together, the nutritional and environmental requirements for biofilm formation appear to be rather species specific. Thus a specific antagonist should be tested for the optimal nutritional conditions for the biofilm formation, according to which various sugars, osmotic agents or salts should be supplemented to the medium for cultivation to provide feasible conditions for biofilm formation.

Currently, most banana plantations are in the condition of imbalanced soil nutrition (such as redundant nutrition in rhizosphere) and improved salinity (due to years of continuous cultivation and preference in employ of $\mathrm{N}, \mathrm{P}$ fertilizer) (Zhong et al., 2011), which stand in the way of biofilm formation. Inadaptability to these conditions would definitely result in the rapid decline in the population of the antagonists, thus weakening the biocontrol efficacy.

The development of time release technology, also known as sustained-release (SR), provides an alternative for this problem. The BCAs are recommended to be introduced into a controlled-release system with sustained release of nutrition, for example, the water retaining agent or the slow-release fertilizers. In this system, the nutrients are provided slowly and steadily for an extended duration, which not only protect the antagonists and facilitate the biofilm formation, but also put banana plants in the way they prefer to be fed and helps them grow well. Considering the water shortage problem, it is desirable to develop a water and nutrition retaining agent to maintain both water and nutrition at the same time. In addition, as mentioned above, high salinity exerts negative influence on the formation of biofilms through an osmotic effect. A recommended approach is to use halo-tolerant microbes from mangrove and marine source as antagonists against Foc pathogens (Xu and Dai, 2007). 


\section{OTHER FACTORS THAT HELP IMPROVE THE BIOCONTROL EFFICACY AGAINST FUSARIUM WILT OF BANANA}

\section{Pay attention to the evolutionary and geographic diversity of Foc}

By comparing DNA sequences of nuclear and mitochondrial genes, O'Donnell et al. (1998) concluded that Fusarium wilt of banana is caused by pathogenic strains with independent evolutionary origins, and the Foc races isolated are geographically distinct. A recent field experiment conducted by us supports this conclusion as well, which found that a biocontrol agent proved to have excellent effect in a field in Ledong, Hainan (having a control effect of $99 \%$ ) exhibited poor performance in the field just $17 \mathrm{~km}$ around (having a control effect of 23\%). Preliminary analysis revealed that the colony morphology and virulence of Foc R4 in the two fields showed significant difference (Mo et al., 2013). Therefore, the evolutional and geographic diversity of the pathogen should be taken into consideration in the screening of antagonists against Foc. In the first screening round, it is recommended to use pathogens from various evolutionary origins and geographic areas as targets, in order to improve the biocontrol efficacy.

\section{Take into account the integrated management of banana nematodes}

Banana nematodes constitute another major threat to banana production all over the world, which cause yield losses of up to 30 to $60 \%$ in many countries (Roderick et al., 2012). The fundamental reason that leads to nematode disease and Fusarium wilt is basically in agreement with previous studies (Zhong et al., 2011; Palomares-Rius et al., 2011), both due to the loss of biodiversity in soil. Banana plants that are infected with nematodes tend to have enhanced susceptibility to Fusarium wilt, even in those lines showing Fusarium tolerance or resistance (Ammar, 2007). Thus, the two diseases could be controlled jointly, and combined management of the two diseases would save us lots of efforts and costs (Pararu et al., 2009). To improve biocontrol efficacy, BCAs against both disease are encouraged to be developed.

\section{Consider addition of non-antagonistic microbes into the biocontrol agents}

Microbes that do not have antagonistic effect to pathogens may act as potential biocontrol agents by occupying the ecological sites of the pathogen or competing with the pathogen for nutritious and infection sites ( $\mathrm{Nel}$ et al., 2006). Therefore, it is recommended to add certain nonantagonistic microbes into the biocontrol agents. Non pathogenic $F$. oxysporum strains can be developed as biocontrol agents. They are able to compete for nutrients in the soil, which affect the rate of chlamydospore germination of the pathogen (Kidane and Laing, 2010). They can also compete with the pathogens for infection sites on the root, and can trigger plant defense reactions, inducing systemic resistance. To give an example, Fo47, a nonpathogenic $F$. oxysporum strains, have been successfully applied as biocontrol agent in the field. Studies revealed that the general pattern of colonization in soil was similar for the pathogenic strain and Fo47. However, Fo47 grew faster than the pathogenic strain and, as a consequence, colonized the rhizosphere earlier (Michielse and Rep, 2009).

\section{Considering using secondary metabolites for biocontrol agents}

Some antagonistic microbes produce antagonistic substances only under the nutrient-poor conditions (Opelt and Berg, 2004). Based on our experience, this kind of microorganisms cannot act as viable biocontrol agents directly (Mo et al., 2013). A better choice is to take advantage of its secondary metabolites. If they are used as potential viable biocontrol agents, relatively poor culture conditions should be applied in the dual-culture assay during the second screening round, for example, cultured in the water agar. Only the microbes that exhibit antagonistic characteristics in the water agar should be chosen for the third screening round.

\section{Avoid using actinomycetes as viable biocontrol agents}

Actinomycetes is not recommended to be applied as viable biocontrol agents for managing Fusarium wilt of banana in Chinese banana plantations, because the favorable conditions needed for actinomycetes to survive is not desirable for the growth of banana roots (Jayasinghe and Parkinson, 2008). However, it is feasible to use the secondary metabolites of Actinomycetes as biocontrol agents.

Introducing limitation factors as many as possible in the screening of antagonists

In the second round of screening for potential BCAs, it is recommended to introduce limitation factors as many as possible, such as extreme $\mathrm{pH}$ and temperature. The antagonistic stains that are tolerant to a wide range of environmental conditions have greater market potential as biocontrol agents against Foc. In other words, the advantageous and competitive microbes have greater chance to colonize heterogeneous habitats and become "indigenous inhabitants" in this environment. The process for the microbes to become "indigenous inhabitants" in heterogeneous habitats is defined by us as "post-indigenousness", and these microbes are designated as "post-indi- 
genous microbes".

As we all know, the most typical feature of strains belonging to Bacillus family is that they can form spores to get through adverse environmental conditions (Vos et al., 2009), which enable them to survive in a board range of environmental conditions. The utility of strains of Bacillus $s p$. as biocontrol agents cannot only obtain sustained colonization in banana plants, but also facilitate the postprocessing, storage and transportation. Therefore, antagonistic strains from Bacillus spp. are a recommended choice as biocontrol agents in field application.

\section{Restoring the soil biodiversity in banana plantations to control Fusarium wilt indirectly}

The most serious problem for banana plantations with years of continuous cultivation is the loss of soil bio diversity (Zhong et al., 2011). Especially, the loss of keystone species in the microbial communities would severely destroy the ecological balance of the environ ment (Walker, 1992), which offers favorable conditions for the accumulation of Foc pathogens. The toxins secreted by these pathogens first attack the roots of banana plants, and then spread to stem and leaves, eventually resulting in outbreak of Fusarium wilt (Kuo and Scheffer, 1964). The growth of banana plants is closely related to the biodiversity in the rhizosphere. Under constant supply of normal nutrition, the roots of the banana plants are well developed. The exudates from the root hairs or root tip promote the growth of rhizosphere organisms (Bais et al., 2006), which in turn enhance the biodiversity of soil.

\section{ACKNOWLEDGEMENTS}

This work was supported by the National Natural Science Foundation of China (No. 31271995), the Fundamental Research Funds for Institute of Tropical Bioscience an d Biotechnology, CATAS (No. ITBB120203), Agro-Tech Extension System Construction Project on Tropical Crops (No. 13RZNJ-39), Department of Agriculture, and Hainan Provincial Key Scientific and Technological Project (ZDZX2013023-1-18).

\section{REFERENCES}

Aguilar EA, Santos PJA, Tamisin LL (2008). Root characteristics of five local banana cultivars (Musa sp.) under waterlogged condition. Phil. J. Crop Sci. 33(3):14-23.

Ammar MI (2007). Fusarium species associated with corm rots and wilt of banana (Musa sp.) under Egyptian conditions. Egypt. J. Phytopathol. 35(2):81-98.

Bais HP, Weir TL, Perry LG, Gilroy S, Vivanco JM (2006). The role of root exudates in rhizosphere interactions with plants and other organisms. Ann. Rev. Plant Biol. 57:233-266.

Bashan Y, Levanony H, Whitmoyer RE (1991). Root surface colonization of non-cereal crop plants by pleomorphic Azospirillum brasilense Cd. J. Gen. Microbiol. 137:187-196.

Bertagnolli BL, Soglio FKD, Sinclair JB (1996). Extracellular enzyme profiles of fungal pathogen Rhizoctonia solani isolate $2 \mathrm{~B}-12$ and of two antagonists, Bacillus megaterium strain B153-2-2 and Trichoderma harzianum isolate Th008. I. Possible correlation with inhibition of growth and biocontrol. Physiol. Mol. Plant Pathol. 48:145-160.

Bevivino A, Peggion V, Chiarini L, Tabacchioni S, Cantale C, Dalmastri C (2005). Effect of Fusarium verticillioides on maize-root-associated Burkholderia cenocepacia populations. Res. Microbiol. 156: 974-983.

Bird DM, Oppermana CH, Davies KG (2003). Interactions between bacteria and plant-parasitic nematodes: now and then. Int J Parasitol. 33:1269-1276.

Bolwerk A, Lagopodi AL, Wijfjes AH, Lamers GE, Chin-A-Woeng TF, Lugtenberg BJ, Bloemberg GV (2003). Interactions in the tomato rhizosphere of two Pseudomonas biocontrol strains with the phyto pathogenic fungus Fusarium oxysporum f. sp. radicis-lycopersici. Mol. Plant Microbe In. 16(11): 983-893.

Burke RA, Molina M, Cox JE., Osher LJ, Piccolo MC (2003). Stable carbon isotope ratio and composition of microbial fatty acids in tropical soils. J. Environ. Qual. 32:198-206.

Candela T, Fouet A (2006). Poly-gamma-glutamate in bacteria. Mol. Microbiol. 60:1091-1098.

Cavaglieri L, Orlando J, Etcheverry M (2005). In vitro influence of bacterial mixtures on Fusarium verticillioides growth and fumonisin B1 production: effect of seeds treatment on maize root colonization. Lett. Appl. Microbiol. 41:390-396.

Chang WS, Halverson LJ (2003). Reduced water availability influences the dynamics, development, and ultrastructural properties of Pseudomonas putida biofilms. J. Bacteriol. 185:6199-6204.

Chao WL, Nelson EB, Harman GE, Hoch HC (1986). Colonization of the rhizosphere by biological control agents applied to seeds. Phytopathol. 76:60-65.

Chen HB (2001). Banana production and demand in China. In: Molina AB, Roa VN, Maghuyop MAG (eds.), Advancing banana and plantain $R$ \& $D$ in Asia and the Pacific-Vol. 10, Proceedings of the 10th INIBAP-ASPNET Regional Advisory Committee meeting held at Bangkok, 2000/11/10-11, INIBAP-ASPNET, Los Baños, pp.92-93.

Christoffersen K, Ahl T, Nybroe O (1995). Grazing of nonindigenous bacteria by nano-sized protozoa in a natural coastal system. Microb. Ecol. 30:67-78.

de-Bashan LE, Bashan Y (2008). Joint immobilization of plant growth-promoting bacteria and green microalgae in alginate beads as an experimental model for studying plant-bacterium interactions. Appl. Environ. Microbiol. 74:6797-6802.

Do TH, Suzuki Y, Abe N, Kaneko J, Itoh Y, Kimura K (2011). Mutations suppressing the loss of DegQ function in Bacillus subtilis (natto) poly- $\gamma$-glutamate synthesis. Appl. Environ. Microbiol. 77(23): 8249-58.

Ekelund F, Rønn R, Christensen S (2001). Distribution with depth of protozoa, bacteria and fungi in soil profiles from three Danish forest sites. Soil Biol.Biochem. 33(4-5): 475-481.

Farhana MSN, Bivi MR, Khairulmazmi A (2011). Effect of carbon sources on bacterial production of metabolites against Fusarium oxysporum and Colletotrichum gloeosporioides. Int. J. Agric. Biol. 13: 1-8.

Fernández-Falcón M, Borges AA, Borges-Pérez A (2003). Induced resistance to Fusarium wilt of banana by exogenous applications of indoleacetic acid. Phytoprotection. 84:149-153.

Fourie G, Steenkamp ET, Gordon TR, Viljoen A (2009). Evolutionary relationships among the Fusarium oxysporum f. sp. cubense vegetative compatibility groups. Appl. Environ. Microbiol. 75: 4770-4781.

Fravel D, Olivain C, Alabouvette C (2003). Fusarium oxysporum and its biocontrol. New Phytol. 157: 493-502.

Goenaga R, Irizarry H (1998). Yield of banana grown with supplemental drip-irrigation on an Ultisol. Expl. Agric. 34:439-448.

Govindasamy V, Senthilkumar M, Magheshwaran V, Kumar U, Bose P, Sharma V, Annapurna K (2011). Bacillus and Paenibacillus spp.: Potential PGPR for Sustainable Agriculture. Microbiol. Monographs. 18: 333-364.

Gurr GM, Wratten SD, Kehrli P, Scarratt S (2005). Cultural manipulations to enhance biological control in Australia and New Zealand: progress and prospects. In: Mark, S.H., ed. "Proceedings of the second International Symposium on Biological Control of Arthropods", Davos, Switzerland, pp.154-166.

Hirsch AM, Bauer WD, Bird DM, Cullimore J, Tyler B, Yoder JI (2003). Molecular signals and receptors: controlling rhizosphere interactions between plants and other organisms. Ecology. 84: 858-868. 
Huang YH, Wang RC, Li CH, Zuo CW, Wei YR, Zhang L, Yi GJ (2012). Control of Fusarium wilt in banana with Chinese leek. Eur. J. Plant Pathol. 134(1):87-95.

Hwang SC, Ko WH (2004). Cavendish banana cultivars resistant to Fusarium Wilt acquired through somaclonal variation in Taiwan. Plant Dis. 88: $580-588$.

Hyakumachi M (2000). Studies on biological control of soilborne plant pathogens. J. Gen. Plant. Pathol., 66: 272-274.

Ingham RE, Trofymow JA, Ingham ER, Coleman DC (1985). Interactions of bacteria, fungi, and their nematode grazers: effects on nutrient cycling and plant growth. Ecol. Monogr. 55:119-140.

Jackson MA (1997). Optimizing nutritional conditions for the liquid culture production of effective fungal biological control agents. Journal of Industrial Microbiology \& Biotechnology, 19:180-187.

Jayasinghe BATD, Parkinson D (2008). Actinomycetes as antagonists of litter decomposer fungi. Appl. Soil Ecol. 38:109-118.

Kidane E.G., Laing MD (2010). Integrated Control of Fusarium Wilt of Banana (Musa spp.). In: Dubois T (Eds), Proc. IC on Banana \& Plantain in Africa, Acta Hort. 879, ISHS, pp. 315-321.

Ko BS, Cho YS, Rhee HK (1996). Controlled release urea from rosin-coated fertilizer particles. Ind. Eng. Chem. Res . 35(1):250-257.

Kuo MS, Scheffer RP (1964). Evaluation of fusaric acid as a factor in development of Fusarium wilt. Phytopathology. 54:1041-1044.

Lian J, Wang ZF, Zhou SN (2008). Response of endophytic bacterial communities in banana tissue culture plantlets to Fusarium wilt pathogen infection. J. Gen. Appl. Microbiol. 54:83-92.

Lunt OR (1968). Modified sulphur coated granular urea for controlled nutrient release. Tans. Ninth Int Congr. Soil Sci. 3:337-383.

Michielse CB, Rep M (2009). Pathogen profile update: Fusarium oxysporum. Mol. Plant Pathol. 10: 311-324.

Mo KL, Zeng T, Chen HQ, Guo G, Zeng HC (2013). Optimization of solid-state fermentation for two Streptomyces stains against banana Fusarium wilt and selection of its additive. Chinese Agricultural Science Bulletin 29:97-102 (in Chinese)

Minerdi D, Moretti M, Gilardi G, Barberio C, Gullino ML, Garibaldi A (2008). Bacterial ectosymbionts and virulence silencing in a Fusarium oxysporum strain. Environ. Microbiol. 10:1725-1741.

Nel B, Steinberg C, Labuschagne N, Viljoen A (2006). Isolation and characterization of nonpathogenic Fusarium oxysporum isolates from the rhizosphere of healthy banana plants. Plant Pathol. 55:207-216.

Nel B, Steinberg C, Labuschagne N, Viljoen A (2006). The potential of nonpathogenic Fusarium oxysporum and other biological control organisms for suppressing Fusarium wilt of banana. Plant Pathol. 55:217-223.

O'Donnell K, Kistler HC, Cigelnik E, Ploetz RC (1998). Multiple evolutionary origins of the fungus causing Panama disease of banana: concordant evidence from nuclear and mitochondrial gene genealogies. Proc. Natl. Acad. Sci., USA. 95:2044-2049.

Opelt K, Berg G (2004). Diversity and antagonistic potential of bacteria associated with bryophytes from nutrient-poor habitats of the Baltic Sea Coast. Appl. Environ. Microbiol. 70(11):6569-6579.

Palomares-Rius JE, Castillo P, Navas-Cortés JA, Jiménez-Díaz RM, Tena $M$ (2011). A proteomic study of in-root interactions between chickpea pathogens: the root-knot nematode Meloidogyne artiellia and the soil-borne fungus Fusarium oxysporum f. sp. ciceris race 5 . J. Proteomics. 74(10): 2034-51.

Pan Y, Breidt F Jr, Gorski L (2010). Synergistic effects of sodium chloride, glucose, and temperature on biofilm formation by Listeria monocitogenes serotype $1 / 2 a$ and $4 b$ strains. Appl. Environ. Microbiol. 76(5): 1433-1441.

Pararu P, Dubois T, Coyne D, Viljoen A (2009). Dual inoculation of Fusarium oxysporum endophytes in banana: effect on plant colonization, growth and control of the root burrowing nematode and the banana weevil. Biocontrol Sci. Techn. 19:639-655.

Persley GJ (1986). Banana and Plantain Breeding Strategies. In: Persley, G.J., De Langhe, E.A., eds. Proceedings of an international workshop held at cairns, Australia. State Mutual Book and Periodical Service, Ltd. pp.13-17.

Pettit RK, Repp KK, Hazen KC (2010). Temperature affects the susceptibility of Cryptococcus neoformans biofilms to antifungal agents. Med. Mycol. 48(2) 421-426

Pieterse CM, van Wees SC, van Pelt JA, Knoester M, Laan R, Gerrits H,
Weisbeek PJ, van Loon LC, (1998). A novel signaling pathway controlling induced systemic resistance in Arabidopsis. Plant Cell 10:1571-1580.

Ploetz RC (1990). Population biology of Fusarium oxysporum f.sp. cubense. In: Ploetz, R.C., ed. Fusarium wilt of banana. St Paul: APS Press, pp. 63-67.

Ploetz RC (1994). Panama disease: return of the first banana menace. Int. J. Pest Manage. 40(4): 326-336.

Ploetz RC (2006). Fusarium Wilt of banana is caused by several pathogens referred to as Fusarium oxysporum f. sp. Cubense. Phytopathology 96(6):653-656.

Ploetz RC, Pegg KG (2000). Fungal disease of the root, corm, and pseudostem: Fusarium wilt. In: Jones DR, ed. Diseases of banana, abaca and enset. London: CAB International, pp. 143-157.

Quintana N, El Kassis EG, Stermitz FR, Vivanco JM (2009). Phytotoxic compounds from roots of Centaurea diffusa Lam. Plant Signal Behav. 4:9-14.

Revdiwala S, Rajdev BM, and Mulla S (2012). Characterization of bacterial etiologic agents of biofilm formation in medical devices in critical care setup. Crit. Care Res. Pract. doi:10.1155/2012/945805

Rinaudi L, Fujishige NA, Hirsch AM, Banchio E, Zorreguieta A, Giordano W (2006). Effects of nutritional and environmental conditions on Sinorhizobium meliloti biofilm formation. Res Microbiol. 157: 867-875.

Rinaudi LV, Giordano W (2010). An integrated view of biofilm formation in rhizobia. FEMS. Microbiol. Lett. 304(1): 1-11.

Roderick H, Mbiru E, Coyne D, Tripathi L, Atkinson HJ (2012). Quantitative digital imaging of banana growth suppression by plant parasitic nematodes. PLoS One. 7(12):e53355.

Ronn R, McCaig AE, Griffiths BS, Prosser JI (2002). Impact of protozoan grazing on bacterial community structure in soil microcosms. Appl. Environ. Microbiol. 68(12):6094-6105.

Rujappan K, Vidhyasekaran P, Sethuraman K, Baskaran TL (2002). Development of powder and capsule formulations of Pseudomonas fluorescens strain Pf-1 for control of banana wilt. Z. Pflanzenk. Pflanzen. (Journal of Plant Diseases and Protection) 109:80-87.

Saravanan T, Muthusamy M, Marimuthu T (2003). Development of integrated approach to manage the fusarial wilt of banana. Crop Prot. 22:1117-1123.

Schallmey M, Singh A, Ward OP (2004). Developments in the use of Bacillus species for industrial production. Can. J. Microbiol. 50:1-17.

Schisler DA, Khan NI, Boehm MJ, Slininger PJ (2002). Greenhouse and field evaluation of biological control of Fusarium Head Blight on Durum Wheat. Plant Dis. 86:1350-1356.

Sessitsch A, Reiter B, Berg G (2004). Endophytic bacterial communities of field-grown potato plants and their plant-growth-promoting and antagonistic abilities. Can. J. Microbiol. 50:239-249.

Shera J, Sriprakash KS, McMillan DJ (2006). The nutritional requirements for biofilm formation by Group A streptococcus. International Congress Series. 1289:139-142.

Stover RH (1958). Studies on Fusarium wilt of bananas: III. Influence of soil fungitoxins on behavior of $F$. oxysporum $\mathrm{f}$. cubense in soil extracts and diffusates. Can. J. Bot. 36(4):439-453.

Stover RH (1962). Fusarial Wilt (Panama Disease) of Bananas and Other Musa Species. Kew, UK: Commonwealth Mycological Institute.

Stover RH, Buddenhagen IW (1986). Banana breeding: Polyploidy, disease resistance and productivity. Fruits 40:175-191.

Stover RH, Simmonds NW (1987). Bananas, 3rd ed. Longmans, London, United Kingdom, pp.29-30

Sun BJ, Peng M, Wang YG, Zhao J, Xia QY (2011). Isolation and characterization of antagonistic bacteria against fusaium wilt and induction of defense related enzymes in banana. Afr. J. Microbiol. Res. 5(5):509-515.

Szczech M, Shoda M (2004). Biocontrol of Rhizoctonia damping-off tomato by Bacillus subtilis combined with Burkholderia cepacia. J. Phytopathol. 152:549-556.

Tan S, Dong Y, Liao H, Huang J, Song S, Xu Y, Shen Q (2013). Antagonistic bacterium Bacillus amyloliquefaciens induces resistance and controls the bacterial wilt of tomato. Pest Manag. Sci. Jan. 21. doi: $10.1002 / p s .3491$

Thangavelu R, Palaniswami A, Velazhahan R (2004). Mass production of Trichoderma harzianum for managing Fusarium Wilt of banana. Agr. Ecosyst. Environ. 103:259-263. 
Tsujimoto T, Kimura J, Takeuchi Y, Uyama H, Park C, Sung MH (2010). Chelation of calcium lons by Poly (gamma-Glutamic Acid) from Bacillus subtilis (Chungkookjang). J. Microbiol. Biotechnol. 20: 1436-1439.

Viljoen A (2002). The status of Fusarium wilt (Panama disease) of banana in South Africa. S. Afr J. Sci. 98:1-4.

Vos P, Garrity G, Jones D, Krieg NR, Ludwig W, Rainey FA, Schleifer KH, Whitman WB, Eds., (2009). Bergey's Manual of Systematic Bacteriology, The Firmicutes. New York, NY: Springer-Verlag, 3: 1-17.

Waite BH (1977). Inoculation studies and natural infection of banana varieties with races 1 and 2 of Fusarium oxysporum f. cubense. Plant Dis. Rep. 61:15-19.

Walker C (1992). Systematics and taxonomy of the arbuscular endomycorrhizal fungi (Glomales): a possible way forward. Agronomie. 12:887-897.

Wang T, Duan YJ, Liu BT, Guo G, Zhou DB, Tan X, Zhang XY, Huang MJ (2011). The Colonization of Two Strains of Antagonistic Bacteria of Fusarium oxysporum in Banana. Gen. Appl. Biol. 30(3):342-350 (in Chinese).

Wardle DA (2006). The influence of biotic interactions on soil biodiversity. Ecol. Lett. 9:870-886.

Webb JS, Givskov M, Kjelleberg S (2003). Bacterial biofilms prokaryotic adventures in muhicellularity. Curt. Opin. Microbioll. 6:578-585.

Xia YK (2011). The economic research of banana production technology in China. Dissertaion for Ph.D., Hainan University, Supervisor: Guo JC, Jin ZQ, pp. 35-36 (in Chinese).

$\mathrm{Xu} \mathrm{XL}$, Dai $P$ (2007). Isolation and identification of two entophytic bacteria strains against Fusarium oxysporum. J. Fruit Sci. 24: 483-486. (in Chinese)
Yilmaz M, Soran H, Beyatli Y (2005). Antimicrobial activities of some Bacillus spp. strains isolated from the soil. Microbiol. Res. 161: 127-131.

Yin XM, Jin ZQ, Xu BY, Ma WH, Fu YG, Wang JB (2011). Characterization of early events in banana root infected with the GFP-tagged Fusarium oxysporum f. sp. cubense. Acta horticulturae, (897): 371-376.

Yu GY, Sinclair JB, Hartman GL, et al (2002). Production of iturinA by Bacillus amyloliquefaciens suppressing Rhizoctonia solani. Soil Biol. Biochem. 34:955-963.

Zeng W, Lin Y, Qi Z, He Y, Wang D, Chen G, Liang Z (2013). An integrated high-throughput strategy for rapid screening of poly (y-glutamic acid)-producing bacteria. Appl. Microbiol. Biotechnol. 97(5): 2163-2172.

Zhong S, He YD, Zeng HC, Mo YW, Jin ZQ (2011). Effects of banana wilt disease on soil nematode community structure and diversity. Afr. J. Biotechnol. 59(10):12759-12767. 